\title{
Helicobacter pylori infection in pregnant women in four districts of Uganda: role of geographic location, education and water sources
}

Rhona Kezabu Baingana ${ }^{1 *}$, John Kiboko Enyaru and Lena Davidsson²

\begin{abstract}
Background: The prevalence of Helicobacter pylori infection varies in relation to geography, ethnicity and socioeconomic factors. Available data on the prevalence of Helicobacter pylori infection in Uganda are not representative of the general population. We sought to describe the epidemiology of this infection in pregnant women in Uganda to provide background data for a study into the effect of $\mathrm{H}$. pylori infection during pregnancy on the hematological response to iron supplementation.
\end{abstract}

Methods: Using a cross-sectional design, H. pylori infection was assessed by the stool antigen test among 447 pregnant women attending antenatal care clinics in Apac, Mbale, Mbarara and Rakai Districts which are in different geographical regions in Uganda, and at Kawempe Health Center which serves a low-income densely populated area in Kampala City. Socio-demographic and household data were collected by face-to-face interviews using a questionnaire. Associations between H. pylori infection and socio-demographic and household characteristics were analyzed using logistic regression.

Results: The overall prevalence of $H$. pylori infection was $45.2 \%$ but varied by geographical location from $18.2 \%$ in Apac District to 60.5\% at Kawempe Health Centre. At 18.4\%, the Langi ethnic group, who were enrolled exclusively in Apac District, had the lowest prevalence of H. pylori infection while the Gisu had the highest prevalence (58.4\%). H. pylori was independently associated with enrollment at clinics not in Apac (adjusted OR $=5.68 ; 95 \%$ Cl: 3.02-10.7) and with using water from public wells, boreholes or springs ( $\mathrm{AOR}=3.20 ; 95 \% \mathrm{Cl}: 1.19-8.61$ ) and from rivers, lakes or streams ( $A O R=5.20 ; 95 \% \mathrm{Cl}: 1.58-17.05)$. Urban residence ( $\mathrm{AOR}=1.71 ; 95 \% \mathrm{Cl}: 1.13-2.60)$ and no formal education $(\mathrm{AOR}=1.95 ; 95 \% \mathrm{Cl}: 1.03-3.67)$ were also independently associated with $\mathrm{H}$. pylori infection.

Conclusions: The unexpected variation in the prevalence of $\mathrm{H}$. pylori infection in Uganda calls for population-based studies in the region and offers an opportunity to study the transmission dynamics of $\mathrm{H}$. pylori infection. The association between $\mathrm{H}$. pylori infection and surface water sources for household use suggests waterborne transmission of H. pylori infection highlighting the need for concerted efforts in environmental health in communities and at the household level.

Keywords: Helicobacter pylori, Uganda, Pregnant women, Geographical, Ethnicity, Water, Education, Rural, Urban

\footnotetext{
* Correspondence: rbaingana@gmail.com

'Department of Biochemistry and Sports Science, College of Natural

Sciences, Makerere University, P. O. Box 7062, Kampala, Uganda

Full list of author information is available at the end of the article
} 


\section{Background}

Helicobacter pylori infection has a major role in the development of gastritis and peptic ulcers and is an important risk factor for gastric cancer [1]. The prevalence of $H$. pylori infection is persistently higher in developing countries than in developed countries [2] and can vary by ethnicity [3-5], place of birth, and socioeconomic factors even among persons living in the same country [6]. Data on H. pylori infection in Uganda are limited and are not representative of the general population: the prevalence was $74 \%$ in patients with dyspepsia referred for endoscopy [7] and 86\% in patients with cancer and benign tumors [8]. Additional data are from a low-income urban setting in Kampala City where the prevalence of $H$. pylori infection in children twelve years and below was $44.3 \%$ based on a stool antigen test [9] and was $63 \%$ based on a serological test in children aged 1-10 years [10]. While these data are informative, the coverage in terms of geographical location and age-group is limited. Additionally, to our knowledge, there is no data from apparently healthy, non-referred adults.

There is compelling evidence from case studies, observational studies and interventional trials in children and non-pregnant adolescents and adults suggesting a role for $H$. pylori infection in the etiology of anemia $[11,12]$. However, the evidence for a similar role in anemia in pregnancy remains inconclusive [13-17]. Because available data on $H$. pylori infection in Uganda are limited and are not representative of the general population, we set out to study the prevalence of $H$. pylori infection in pregnant women in Uganda so as to provide background data for a study into the effect of $H$. pylori infection on the hematological response to iron supplementation in pregnant women in Uganda.

Among the tests available for the diagnosis of $H$. pylori infection, the invasive ones (endoscopy with biopsy for histology, culture, and rapid urease test) are not suitable for pregnant women. Serological tests do not discriminate between current and past infections. The noninvasive "gold standard" ${ }^{13} \mathrm{C}$ urea breath test was not available for this study for logistic reasons. The stool antigen test offers a simple, yet robust alternative $[18,19]$ which has been recommended by the European Helicobacter Study Group as one of two non-invasive tests (the other being the urea breath test) [20]. We used the stool antigen test to determine $H$. pylori infection and described the association of $H$. pylori infection with well-known risk factors including ruralurban residence, sources of water for household use and educational attainment in pregnant women attending antenatal care at health facilities in various regions in Uganda.

\section{Methods}

\section{Study setting and design}

Uganda, a land-locked country in East Africa has over 40 geographically localised ethnic groups. The Baganda in the south-central region form the largest group, comprising almost $18 \%$ of the population. The other major ethnic groups are Banyankole (10\%), Basoga (9\%,) Iteso (8\%), Bakiga 7\%, Langi (6\%), Bagisu (5\%), Acholi (5\%) [21]. This was a cross-sectional study in which four districts: Apac, Mbale, Mbarara and Rakai, were purposively selected from the pilot districts of the Innovations at Makerere Committee program to represent different geographical locations and the major ethnic groups in the country (Figure 1). Kawempe Health Centre in Kampala District was purposively selected for comparison as a health facility that serves a densely-populated, low-income area. Within each district, four health facilities were purposively selected to represent rural and urban settings and to include a wide geographic area within the district.

\section{Study population and sample size}

The study population consisted of pregnant women attending antenatal care clinics (ANC) at health facilities in Apac (Apac Hospital, Alenga Health Centre (HC) III, Abongomola HC III Aboke HC III), Mbale (Mbale Hospital, Bududa Hospital, Bunambale HC II Busano HC II), Mbarara (Bwizibwera HC IV, Bugamba HC IV, Kinoni HC IV, Mbarara MC HC IV) and Rakai (Rakai Hospital, Lyantonde Hospital, Kibale HC II, Bethlehem HC II) and at Kawempe HC IV in Kampala District. According to the 2006 and 2011 Uganda Demographic and Health Surveys $94 \%$ of pregnant women attend antenatal care at least once $[22,23]$, thus pregnant women attending ANC are representative of pregnant women in our setting.

Available data at the time of planning the study indicated that the prevalence of $H$. pylori infection was $74 \%$ in patients with dyspepsia referred for endoscopy in Uganda [7] and ranged from $70 \%$ to $100 \%$ in adults in Africa [24,25]. A sample size of 322 women would be needed to estimate a prevalence of $70 \%$ with a confidence level of $95 \%$ and a precision of 5\% [26]. However, because this was the first study in apparently healthy, non-referred adults in Uganda, and because we wanted to achieve a wider coverage of the country compared to a previous study [7], our aim was to recruit about 500 women.

\section{Data collection}

Data were collected from Rakai and Mbale Districts from August to October 2005, from Kawempe Health Centre in February and March 2006 and from Mbarara and Apac Districts from February to April 2008. The protracted data collection period was due to logistics challenges.

On each day of data collection, the background, aims and procedures of the study were first explained to the health workers of the antenatal care clinic and then to the women attending the clinic collectively. The women 


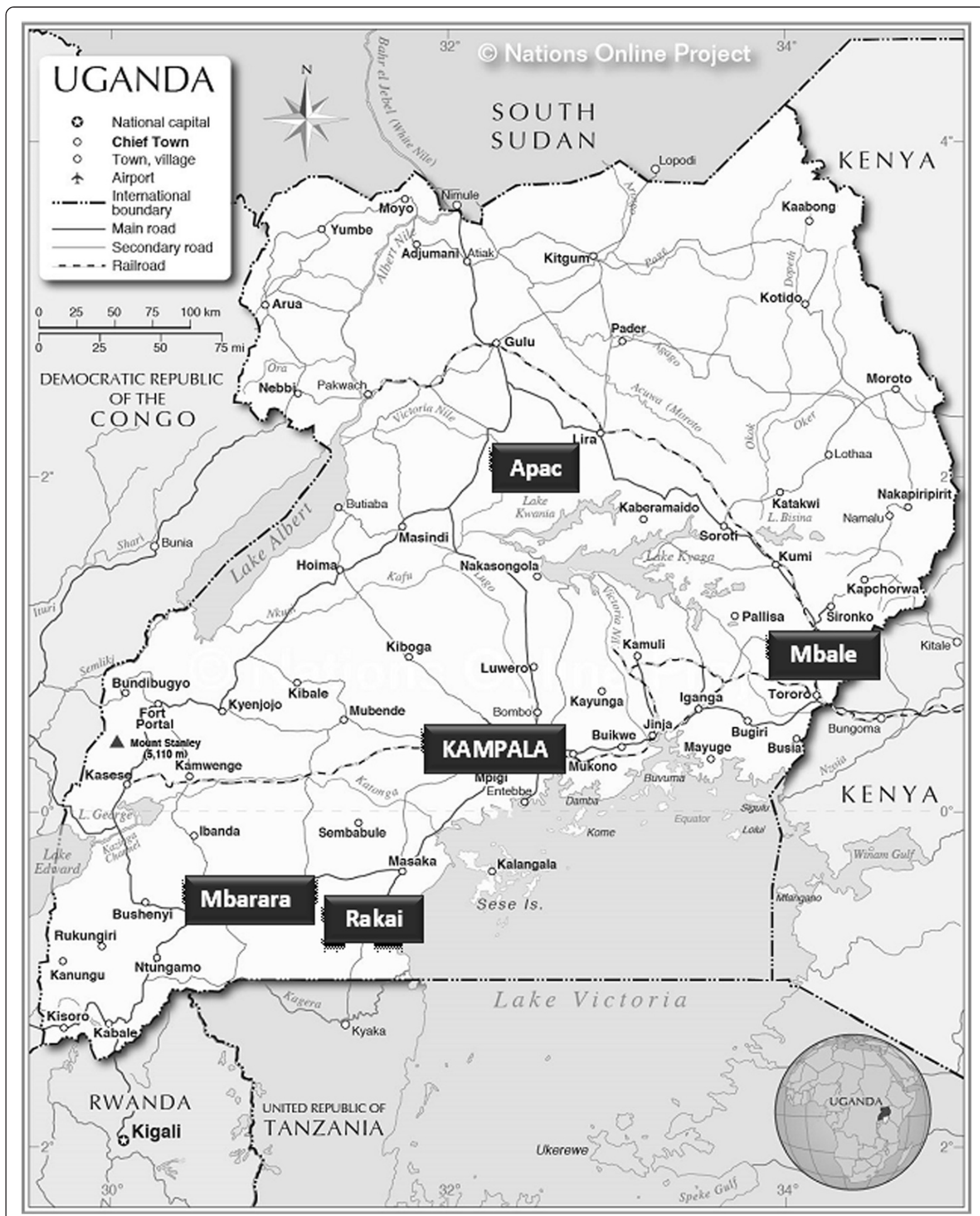

Figure 1 Map of Uganda showing study areas. 
who came for antenatal care on the days of data collection at each health facility were approached consecutively to participate in the study. Any woman who had pregnancy-related complications or reported that she used antibiotics in the two weeks preceding data collection was excluded from the study. Informed written consent was given by each subject, and the study was performed according to the Declaration of Helsinki. The study was approved by Makerere University Faculty of Medicine Research and Ethics Committee and research clearance was obtained from Uganda National Council for Science and Technology.

After receiving consent, socioeconomic and demographic data were collected through interviews using a questionnaire. Information collected included the women's age, parity, reported gestational age, educational level and employment status. We also assessed household characteristics such as household size, number of rooms, sources of water for household use, housing materials and ownership of household assets. Consenting women were given clearly labeled stool sample bottles for self-collection of stool. Women who were unable to provide the stool sample on the spot were requested to bring it at the next scheduled data collection visit if it was feasible for them to return. Stool samples were transported to the Department of Biochemistry at Makerere University in Kampala, Uganda on ice-packs in a cool box and were analyzed the same day or were stored in a refrigerator $\left(4-8^{\circ} \mathrm{C}\right)$ or frozen $\left(-20^{\circ} \mathrm{C}\right)$ pending analysis. None of the samples was kept for more than 48 hours at $4-8^{\circ} \mathrm{C}$ or for more than 7 days at $-20^{\circ} \mathrm{C}$ before analysis. Stool samples were analyzed using a $\mathrm{H}$. pylori stool antigen test (Premier Platinum HpSA, Meridian Diagnostics Inc., Cincinnati, $\mathrm{OH}, \mathrm{USA}$ ) following the manufacturer's instructions. According to the manufacturer, the test is $96.1 \%$ sensitive and $95.7 \%$ specific. In brief, diluted stool samples were put into microplate wells followed by peroxidase-conjugated antibody. The wells were incubated for 1 hour at room temperature then washed to remove any unbound material, and a substrate was added to each well. After $10 \mathrm{mi}-$ nutes incubation, stop solution was added and the result determined spectrophotometrically at $450 / 630 \mathrm{~nm}$ as per the manufacturer's recommendations. Positive and negative controls were run with each assay. Results were expressed as $H$. pylori positive or negative.

\section{Data analysis}

Principal components analysis was used to assign a weight to the following household assets: type of house (mud and wattle or cement and bricks), nature of floor (packed soil or cement/tiles), type of roof (grass-thatched or iron sheets/tiles); ownership of a watch, radio, bicycle, mobile phone, land, domestic animals, a motorised vehicle (car or motorcycle) and television, subject's employment status and whether the household hired laborers. The KaiserMeyer-Olkin Measure of Sampling Adequacy which reflects the proportion of common variance in the variables was 0.79 while Barlett's Test of Sphericity was statistically significant, indicating significant relationships between the variables. Four components with eigenvalues higher than 1 were extracted; the first accounted for $27.8 \%$ of the total variance and was selected as the socio-economic score. The socio-economic score was ranked and categorized into wealth quintiles (Lowest, Second, Middle, Fourth, Highest).

Cross-tabulation was used to obtain frequencies and proportions of background characteristics by location and of $H$. pylori infection by background characteristics. Univariate logistic regression was used to assess crude associations between $H$. pylori infection and risk factors. Given that ethnic groups in Uganda are geographically localized, there is a high correlation between ethnic group and district in our data $(r=0.358, p=0.000)$. Thus, ethnic group was not included in the subsequent analysis. Bivariate logistic regression was used to assess the relationship of $H$. pylori infection to risk factors whilst controlling for location. The risk factors associated with $H$. pylori following univariate and/or bivariate analysis (at $p \leq 0.05)$ were entered into a multivariable logistic regression to select the final set of independent risk factors. The final multiple logistic regression model fit was determined by the Hosmer-Lemeshow test statistic [27]. A model fits the data if the Hosmer-Lemeshow statistic has a $p>0.05$. All statistical analyses were performed using SPSS 13.0 for Windows (SPSS Inc).

\section{Results}

Of the 502 women who consented, 38 did not provide stool samples. Seventeen stool samples were omitted for poor quality, leaving a total of 447 women in the study. The demographic and household characteristics are summarized in Table 1. Just over half of the women were rural residents and $61 \%$ were 24 years of age or less. Only $12.5 \%$ of the women did not have any formal education and $94.6 \%$ used pit latrines. About two-thirds collected water for household use from public wells, boreholes or springs. Apac had the highest proportion of women in the lowest wealth quintile (58\%) while Kawempe Health Centre had the highest proportion of women in the highest wealth quintile (69\%).

\section{H. pylori infection and demographic and household characteristics}

Helicobacter pylori antigens were found in the stool of 202 of the 447 women who provided stool samples, giving a prevalence of $45.2 \%$ (95\% Confidence Interval (CI) 40.3-50.1\%). The prevalence ranged from 18.2\% (95\% CI: 10.2-26.3\%) in Apac to $60.5 \%$ (95\% CI: $50.2-70.8 \%$ ) at 
Table 1 Demographic and household characteristics by location

\begin{tabular}{|c|c|c|c|c|c|c|c|c|c|c|c|c|c|}
\hline \multirow[t]{3}{*}{ Characteristic } & & \multirow{2}{*}{\multicolumn{2}{|c|}{$\begin{array}{c}\text { Kawempe } \\
(\mathrm{N}=86)\end{array}$}} & \multirow{2}{*}{\multicolumn{2}{|c|}{$\begin{array}{c}\text { Mbale } \\
(N=107)\end{array}$}} & \multirow{2}{*}{\multicolumn{2}{|c|}{$\begin{array}{l}\text { Mbarara } \\
(\mathrm{N}=105)\end{array}$}} & \multirow{2}{*}{\multicolumn{2}{|c|}{$\begin{array}{c}\text { Rakai } \\
(N=61)\end{array}$}} & \multirow{2}{*}{\multicolumn{2}{|c|}{$\begin{array}{c}\text { Apac } \\
(\mathrm{N}=\mathbf{8 8})\end{array}$}} & \multirow{2}{*}{\multicolumn{2}{|c|}{$\begin{array}{c}\text { Total } \\
(\mathrm{N}=447)\end{array}$}} \\
\hline & & & & & & & & & & & & & \\
\hline & & $n$ & $\%$ & $\mathrm{n}$ & $\%$ & $n$ & $\%$ & $n$ & $\%$ & $\mathrm{n}$ & $\%$ & $n$ & $\%$ \\
\hline \multirow[t]{2}{*}{ Residence } & Urban & 86 & 100 & 65 & 60.7 & 10 & 9.1 & 50 & 82.0 & 35 & 39.8 & 246 & 55.0 \\
\hline & Rural & 0 & 0 & 42 & 39.3 & 95 & 90.9 & 11 & 18.0 & 53 & 60.2 & 201 & 45.0 \\
\hline \multirow[t]{6}{*}{ Age (years) } & $15-19$ & 18 & 20.9 & 25 & 23.4 & 25 & 23.6 & 10 & 16.7 & 17 & 19.3 & 95 & 21.3 \\
\hline & $20-24$ & 41 & 47.7 & 36 & 33.6 & 42 & 39.6 & 25 & 41.7 & 34 & 38.6 & 178 & 39.9 \\
\hline & $25-29$ & 18 & 20.9 & 24 & 22.4 & 15 & 14.2 & 11 & 18.3 & 16 & 18.2 & 84 & 18.8 \\
\hline & $30-34$ & 5 & 5.8 & 16 & 15.0 & 16 & 15.1 & 10 & 16.7 & 12 & 13.6 & 59 & 13.2 \\
\hline & $35-39$ & 4 & 4.7 & 5 & 4.7 & 6 & 5.7 & 4 & 6.7 & 5 & 5.7 & 24 & 5.4 \\
\hline & $40-44$ & 0 & 0 & 1 & 0.9 & 2 & 1.9 & 0 & 0 & 3 & 3.4 & 6 & 1.3 \\
\hline Married & & 72 & 83.9 & 100 & 93.5 & 99 & 94.5 & 56 & 91.8 & 79 & 98.5 & 406 & 90.8 \\
\hline \multirow[t]{2}{*}{ Education } & None & 5 & 5.7 & 16 & 15.0 & 11 & 10.1 & 8 & 13.1 & 16 & 18.2 & 56 & 12.5 \\
\hline & Primary+ & 81 & 94.3 & 91 & 85.0 & 94 & 89.9 & 53 & 86.9 & 72 & 81.8 & 391 & 87.5 \\
\hline \multirow[t]{2}{*}{ Parity } & $\leq 2$ & 67 & 77.9 & 55 & 51.4 & 68 & 65.1 & 36 & 59.0 & 44 & 50.0 & 270 & 60.4 \\
\hline & $3+$ & 19 & 22.1 & 52 & 48.6 & 37 & 34.9 & 25 & 41.0 & 44 & 50.0 & 177 & 39.6 \\
\hline \multirow[t]{3}{*}{ Toilet } & None & 1 & & 5 & 4.7 & 0 & 0 & 0 & 0 & 3 & 3.4 & 9 & 2.0 \\
\hline & Flush & 6 & 6.9 & 6 & 5.6 & 2 & 1.9 & 1 & 1.6 & 0 & 0 & 15 & 3.4 \\
\hline & Pit latrine & 79 & 92.0 & 96 & 89.7 & 103 & 98.1 & 60 & 98.4 & 85 & 96.6 & 423 & 94.6 \\
\hline \multirow[t]{3}{*}{ Household crowding } & Low & 3 & 3.5 & 12 & 11.2 & 19 & 18.2 & 9 & 14.8 & 6 & 6.8 & 49 & 11.0 \\
\hline & Medium & 50 & 58.1 & 79 & 73.8 & 80 & 76.4 & 42 & 68.9 & 58 & 65.9 & 309 & 69.1 \\
\hline & High & 33 & 38.4 & 16 & 15.0 & 6 & 5.5 & 10 & 16.4 & 24 & 27.3 & 89 & 19.9 \\
\hline \multirow[t]{5}{*}{ Ethnic group } & Ganda & 55 & 64.0 & 2 & 1.9 & 0 & 0 & 36 & 59.0 & 0 & 0 & 93 & 20.8 \\
\hline & Lango & 0 & 0 & 0 & 0 & 0 & 0 & 0 & 0 & 87 & 98.9 & 87 & 19.5 \\
\hline & Gisu & 3 & 3.5 & 98 & 91.6 & 0 & 0 & 0 & 0 & 0 & 0 & 101 & 22.6 \\
\hline & Nkole & 18 & 20.9 & 0 & 0 & 103 & 98.2 & 20 & 32.8 & 0 & 0 & 141 & 31.5 \\
\hline & Others & 10 & 11.6 & 7 & 6.5 & 2 & 1.8 & 5 & 8.2 & 1 & 1.1 & 25 & 5.6 \\
\hline \multirow[t]{5}{*}{ Wealth Index } & Lowest & 0 & 0 & 15 & 14.0 & 18 & 17.3 & 10 & 16.4 & 51 & 58.0 & 94 & 21.0 \\
\hline & Second & 0 & 0 & 26 & 24.3 & 24 & 22.7 & 7 & 11.5 & 26 & 29.5 & 83 & 18.6 \\
\hline & Middle & 2 & 2.3 & 43 & 40.2 & 22 & 20.9 & 15 & 24.6 & 7 & 8.0 & 89 & 19.9 \\
\hline & Fourth & 25 & 28.7 & 14 & 13.1 & 31 & 29.1 & 15 & 24.6 & 3 & 3.4 & 88 & 19.7 \\
\hline & Highest & 59 & 69.0 & 9 & 8.4 & 11 & 10.0 & 14 & 23.0 & 0 & 0 & 93 & 20.8 \\
\hline \multirow[t]{4}{*}{ Water source } & Home tap & 5 & 5.7 & 5 & 4.7 & 2 & 1.8 & 9 & 14.8 & 2 & 2.3 & 23 & 5.1 \\
\hline & Public tap & 44 & 51.7 & 17 & 15.9 & 33 & 31.2 & 7 & 11.5 & 1 & 1.1 & 102 & 22.8 \\
\hline & Public WBS & 35 & 40.2 & 78 & 72.9 & 66 & 63.3 & 35 & 57.4 & 66 & 75.0 & 280 & 62.6 \\
\hline & RLS & 2 & 2.3 & 7 & 6. & 4 & 3.7 & 10 & 16.4 & 19 & 21.6 & 42 & 9.4 \\
\hline
\end{tabular}

$\mathrm{WBS}=$ well, borehole or spring; RLS = River, lake or stream.

Kawempe Health Centre. Geographic location, ethnic group, residence and parity were associated with $H$. pylori infection (Table 2). At $18.4 \%$, the prevalence of $H$. pylori infection among the women enrolled in Apac was significantly lower than the prevalence in the other locations (Table 2) thus we used Apac as the reference category when controlling for location. Women enrolled at Kawempe Health Centre had 7-fold higher odds of $H$. pylori infection compared to women enrolled in Apac
(Table 2), while the odds of infection were 3 to 5 -fold higher in women enrolled in the other districts compared to women enrolled in Apac. With the exception of Kampala, which is the capital city and therefore has the highest ethnic diversity, there is a high correlation between ethnic groups and location in Uganda. Accordingly, the odds of $H$. pylori infection in the ethnic groups followed a similar pattern to the odds of infection based on location. Women enrolled at urban health 
Table 2 Prevalence of $H$. pylori infection by demographic and socio-economic variables

\begin{tabular}{|c|c|c|c|c|c|c|}
\hline \multicolumn{2}{|c|}{ Variable (No. of women) } & \multirow{2}{*}{$\begin{array}{l}\text { H. pylori + } \\
\%(95 \% \mathrm{Cl}) \\
18.2(10.2-26.3)\end{array}$} & \multirow{2}{*}{$\begin{array}{l}\text { Univariate } \\
\text { OR }(95 \% \mathrm{Cl}) \\
1.00\end{array}$} & \multirow[t]{2}{*}{$p$} & \multirow{2}{*}{$\begin{array}{l}\text { Adjusted for location } \\
\text { AOR }(95 \% \mathrm{Cl}) \\
-\end{array}$} & \multirow{2}{*}{$\begin{array}{l}p \\
-\end{array}$} \\
\hline \multirow[t]{6}{*}{ Location } & Apac (88) (Ref) & & & & & \\
\hline & Kawempe Health Centre (86) & $60.5(50.2-70.8)$ & $7.02(3.51-14.01)$ & 0.00 & - & - \\
\hline & Mbale (107) & $55.1(45.7-64.5)$ & $5.53(2.85-10.73)$ & 0.00 & - & - \\
\hline & Mbarara (105) & $42.9(33.4-52.4)$ & $3.45(1.78-6.70)$ & 0.00 & - & - \\
\hline & Rakai (61) & $49.2(36.7-61.7)$ & $4.36(2.08-9.11)$ & 0.00 & - & - \\
\hline & All without Apac (359) & $51.8(46.6-57.0)$ & $4.89(2.74-8.73)$ & 0.00 & - & - \\
\hline \multirow[t]{5}{*}{ Ethnic group } & Lango $^{1}$ (87) (Ref) & $18.4(10.3-26.5)$ & 1.00 & & - & - \\
\hline & Nkole $^{2}$ (142) & $46.5(38.3-54.7)$ & $3.85(2.04-7.27)$ & 0.00 & - & - \\
\hline & Gisu $^{3}(101)$ & $58.4(48.8-68.0)$ & $6.23(3.19-12.20)$ & 0.00 & - & - \\
\hline & Ganda $^{4}(93)$ & $55.9(45.8-66.0)$ & $5.63(2.85-11.10)$ & 0.00 & - & - \\
\hline & Others $^{5}(24)$ & $37.5(18.1-56.9)$ & $2.96(1.13-7.78)$ & 0.03 & - & - \\
\hline \multirow[t]{2}{*}{ Residence } & Rural (202) (Ref) & $37.3(30.9-44.3)$ & 1.00 & & 1.00 & \\
\hline & Urban (246) & $51.6(45.4-57.8)$ & $1.79(1.23-2.62)$ & 0.00 & $1.58(1.06-2.34)$ & 0.03 \\
\hline \multirow[t]{6}{*}{ Age $\left(\right.$ years) ${ }^{6}$} & $15-19$ (95) (Ref) & $53.2(43.1-63.3)$ & 1.00 & & 1.00 & \\
\hline & $20-24(178)$ & $44.9(37.6-52.2)$ & $0.72(0.44-1.19)$ & 0.20 & $0.71(0.42-1.20)$ & 0.20 \\
\hline & $25-29(84)$ & $42.2(31.6-52.8)$ & $0.64(0.35-1.16)$ & 0.14 & $0.63(0.34-1.17)$ & 0.14 \\
\hline & $30-34(59)$ & $37.3(25.0-49.6)$ & $0.52(0.27-1.02)$ & 0.06 & $0.51(0.26-1.03)$ & 0.06 \\
\hline & $35-39(24)$ & $45.8(28.3-64.2)$ & $0.76(0.30-1.83)$ & 0.52 & $0.76(0.30-1.94)$ & 0.56 \\
\hline & $40-44(6)$ & $16.7(0.9-58.1)$ & $0.18(0.02-1.57)$ & 0.12 & $0.24(0.03-2.35)$ & 0.22 \\
\hline \multirow[t]{2}{*}{ Marital status } & Not married ${ }^{7}$ (39) & $46.2(30.6-61.8)$ & 1.00 & & 1.00 & \\
\hline & Married (406) & $45.3(34.4-68.6)$ & $0.97(0.50-1.88)$ & 0.93 & $0.91(0.46-1.82)$ & 0.79 \\
\hline \multirow[t]{2}{*}{ Education status } & Primary and above (392) (Ref) & $43.9(39.0-48.8)$ & 1.00 & & 1.00 & \\
\hline & None (56) & $55.4(42.4-68.4)$ & $1.59(0.90-2.79)$ & 0.11 & $1.98(1.08-3.63)$ & 0.03 \\
\hline \multirow[t]{2}{*}{ Parity } & $\leq 2(270)$ & $49.3(43.3-55.3)$ & 1.00 & & 1.00 & \\
\hline & $3+(176)$ & $38.6(31.4-45.8)$ & $0.64(0.44-0.95)$ & 0.03 & $0.71(0.47-1.05)$ & 0.09 \\
\hline \multirow[t]{3}{*}{$\mathrm{HCl}^{8}$} & Low (50) & $52.0(38.2-65.8)$ & 1.00 & & 1.00 & \\
\hline & Medium (309) & $44.7(34.3-45.3)$ & $0.75(0.41-1.36)$ & 0.34 & $0.81(0.44-1.49)$ & 0.50 \\
\hline & High (89) & $43.8(41.9-62.7)$ & $0.72(0.36-1.44)$ & 0.35 & $0.88(0.43-1.81)$ & 0.73 \\
\hline \multirow[t]{4}{*}{ Water source } & Own tap (23) (Ref) & $40.9(20.8-61.0)$ & 1.00 & & 1.00 & \\
\hline & Public tap (104) & $52.5(42.9-62.1)$ & $2.94(1.08-8.06)$ & 0.04 & $2.71(0.98-7.49)$ & 0.05 \\
\hline & Public well, borehole or spring (280) & $43.3(37.5-49.1)$ & $2.25(0.86-5.88)$ & 0.10 & $2.90(1.09-7.68)$ & 0.03 \\
\hline & River, lake, or stream (41) & $48.8(33.5-64.1)$ & $2.70(0.87-8.22)$ & 0.08 & $5.45(1.67-17.80)$ & 0.01 \\
\hline \multirow[t]{3}{*}{ Toilet } & None (8) (Ref) & $37.5(4.0-71.0)$ & 1.00 & & 1.00 & \\
\hline & Flush (15) & $33.3(9.4-57.2)$ & $0.63(0.11-3.41)$ & 0.59 & $0.39(0.06-2.26)$ & 0.29 \\
\hline & Pit latrine (423) & $45.9(41.2-50.6)$ & $1.06(0.28-4.00)$ & 0.93 & $0.86(0.21-3.56)$ & 0.84 \\
\hline \multirow[t]{5}{*}{ Wealth Quintile } & Lowest (94) (Ref) & $34.0(25.2-44.1)$ & 1.00 & & 1.00 & \\
\hline & Second (83) & $44.6(34.4-55.3)$ & $1.57(0.86-2.86)$ & 0.15 & $0.85(0.43-1.69)$ & 0.65 \\
\hline & Middle (89) & $43.8(34.0-54.2)$ & $1.54(0.84-2.85)$ & 0.16 & $0.76(0.38-1.54)$ & 0.45 \\
\hline & Third (88) & $46.6(36.5-56.9)$ & $1.74(0.94-3.19)$ & 0.08 & $0.74(0.37-1.52)$ & 0.42 \\
\hline & Highest (93) & $54.8(44.7-64.6)$ & $2.44(1.33-4.48)$ & 0.00 & $1.00(0.49-2.04)$ & 0.99 \\
\hline
\end{tabular}

'Lango and Acholi; ${ }^{1}$ Nkole, Kiga, Nyarwanda, Bafumbira; ${ }^{3}$ Gisu, Banyole, Luuya, Bagwere; ${ }^{4}$ Ganda, Baruuli, Soga, Bakooki; ${ }^{5}$ Tooro, Alur, Nubbi, Iteso, Lugbara, Tanzanian, Nyoro, Bakonjo, Karamajong, Japadhola. ${ }^{6}$ Mean age $=24.1$ years, range $15-42$ years. ${ }^{7}$ Not married includes never married, widowed and divorced. ${ }^{8} \mathrm{HCl}=$ Household Crowding index: ratio of the number of persons in the household to the number of rooms in the house. Ref $=$ Reference category. 
facilities had 1.79 times higher odds of $H$. pylori infection compared to women enrolled at rural centers; this difference reduced but remained significant after controlling for location.

The odds of $H$. pylori infection among women with no education relative to women with some formal education was not significant in the univariate analysis, however, when location was controlled for, the odds ratio was 1.98 (95\% CI: $1.08-3.63, p=0.03)$ relative to women with some formal education. Women from the highest wealth quintile had higher odds of $H$. pylori infection relative to women from the lowest quintile $(\mathrm{OR}=2.44$; 95\% CI: 1.33-4.48, $p=0.00$ ); controlling for location eliminated this relationship. After controlling for location, women who get water from public wells, boreholes or springs and from rivers, lakes or streams respectively had 3 and 5 -fold higher odds of infection relative to women who have their own taps at the household. The other household characteristics were not associated with H. pylori infection.

\section{Multivariable model}

Urban residence (adjusted OR $=1.71 ; 95 \% \mathrm{CI}$ : 1.13-2.60, $\mathrm{p}=0.02)$ and no formal education $(\mathrm{AOR}=1.95 ; 95 \% \mathrm{CI}$ : 1.03-3.67, $\mathrm{p}=0.04$ ) each had an independent and positive association with $H$. pylori infection (Table 3). Enrollment outside Apac $(\mathrm{AOR}=5.68 ; 95 \% \mathrm{CI}$ : 3.02-10.7, $\mathrm{p}=$ $0.00)$ and using water from public wells, boreholes or springs $(A O R=3.20 ; 95 \% \mathrm{CI}: 1.19-8.61, \mathrm{p}=0.02)$ and from rivers, lakes or streams $(\mathrm{AOR}=5.20$; 95\% CI: 1.58 $17.05, \mathrm{p}=0.01$ ) were also independently positively associated with $H$. pylori infection.

Table 3 Logistic regression model of Helicobacter pylori infection on predictor variables

\begin{tabular}{lll}
\hline Characteristic & Adjusted $^{\mathbf{1}}$ OR (95\% Cl) & $\boldsymbol{p}$ \\
\hline Location & 1.00 & \\
Apac (Ref) & $5.68(3.02-10.7)$ & 0.000 \\
All without Apac & & \\
Residence & 1.00 & 0.017 \\
Rural (Ref) & $1.71(1.13-2.60)$ & \\
Urban & & 0.040 \\
Education status & 1.00 & \\
Primary and above (Ref) & $1.95(1.03-3.67)$ & 0.053 \\
None & & 0.022 \\
Water source & 1.00 & 0.007 \\
Own tap & $2.74(0.99-7.61)$ & \\
Public tap & $3.20(1.19-8.61)$ & \\
Public well, borehole, spring & $5.20(1.58-17.05)$ & \\
River, lake, spring (Ref) & & \\
\hline
\end{tabular}

${ }^{1}$ Adjusting for location, residence, education, water source.

\section{Discussion}

In this sample of pregnant women attending ANC clinics at selected health facilities in Uganda in the districts of Apac, Mbale, Mbarara and Rakai and at Kawempe Health Centre in Kampala District, the prevalence of $H$. pylori infection on the basis of presence of H. pylori stool antigens was $45 \%$ and ranged from $18 \%$ in Apac to $60 \%$ at Kawempe Health Centre. Previous data for adults in Uganda indicate $H$. pylori infection rates of $74 \%$ [7] and $86 \%$ [8]; however, these data were based on patients in Kampala District who had been referred for endoscopy or had cancer and benign tumors and were therefore not representative of the general population. $H$. pylori infection based on a stool antigen test was $44.3 \%$ in children twelve years and below [9] and $63 \%$ based on a serological test in children aged 110 years in the same low-income urban setting in Kampala City [10]. Because prevalence data from pregnant women have been found to typically reflect $H$. pylori prevalence among the general population [28-30], we believe our data provide useful information regarding the distribution of $H$. pylori infection in the country.

While the overall prevalence of $H$. pylori infection found in this study is consistent with most other studies in Africa, the variation by geographical location was unexpected. The prevalence of infection among women enrolled in Apac was significantly lower than the rates in the other locations in Uganda and was lower than rates typically reported for Africa. In a study among pregnant women recruited at ANC clinics in Pemba, Zanzibar, the prevalence of $H$. pylori infection by the ${ }^{13} \mathrm{C}$ urea breath test was $17.5 \%$ and was associated with enrollment at clinics located along a major road [31]. The authors suggested that the distribution of infection reflected higher contact with the outside world experienced along the major highway. Interestingly, a recent study in Cameroun found that the prevalence of $H$. pylori infection among the Baka Pygmies who live in the rainforests of Cameroun, Congo and Gabon was much lower than among their neighbouring non-Baka [32]. The authors suggest that the Baka acquired their $H$. pylori infections from non-Baka neighbors and the frequency of $H$. pylori infection of the Baka is probably limited by population size and other demographic factors [32]. The existence of geographically localized population groups with low $H$. pylori prevalence in developing country settings that are otherwise expected to have a high prevalence was first reported in the northeastern Peninsula Malaysia where ethnic Malays, who comprise $90 \%$ of the population have an extraordinarily low $H$. pylori prevalence as compared with the Chinese or Indian populations living in the same region (reviewed by Lee et al. [33]). Similar to the Baka of Cameroun, H. pylori infection in Malays is related to transmission from non-Malay immigrants and the 
transmission of the infection has been limited by minimal contact with the immigrants as well as other factors yet to be described [33]. Apac District is in the part of northern Uganda that was, until recently, affected by civil strife. Contact with the rest of the country was limited; this is reflected in the fact that only one of the 88 women enrolled at the four health facilities located in diverse areas of Apac was not of the Lango ethnic group, while all the Langi in the study were, without exception, enrolled in Apac. Furthermore, at 65 persons per square kilometer, Northern Uganda has the lowest population density in Uganda [21]. Moreover, Apac was not markedly different from the other locations with regard to background characteristics apart from having the highest proportion of women in the lowest wealth quintile. These findings suggest that the lower population density and relative socioeconomic isolation of the area are factors to consider in the low prevalence of $H$. pylori infection in this area of Uganda. Information regarding $H$. pylori infection in areas bordering Northern Uganda is scarce; a study in Sudan using the rapid urease test and culture to diagnose $H$. pylori infection found a prevalence of $16 \%$ in normal control subjects compared to $80 \%$ in patients with gastritis and $56 \%$ in patients with duodenal ulcer [34]. It would be of interest to study the epidemiology of $H$. pylori infection in the region as a whole as well as examining whether the low prevalence of $\mathrm{H}$. pylori among the Langi is due to the "racial cohort" phenomenon as has been demonstrated for the Malays [33].

The positive association between $H$. pylori infection and wealth quintile obtained from univariate analysis was eliminated after adjusting for location. Moreover, Apac, which had the highest proportion of women in the lowest wealth quintile, had the lowest prevalence of $H$. pylori infection. The relationship between $H$. pylori infection and socioeconomic status in developing countries is not consistent: several studies have found an inverse relationship [35-39] while Farag et al. [31] found a positive relationship. Other studies have not found any relationship [9,40,41]. The different contexts of low socio-economic status in these studies may account for the inconsistency: in some studies such as ours, low socio-economic status is associated with rural areas. To further illustrate, in Uganda, 2.9\% and $72.7 \%$ of urban households respectively are in the lowest and highest wealth quintiles, compared to $22.5 \%$ and $12.3 \%$ of rural households respectively [22]. Farag et al. [31] also reported that women attending antenatal care clinics located at a distance from a major road had lower socio-economic status and lower rates of infection compared to women enrolled at antenatal clinics located at the main road. In other studies the context of lower socio-economic status is urban crowded living conditions [35-37,39]. We also found a higher prevalence of $H$. pylori among the women enrolled at Kawempe
Health Centre, which serves a densely-populated lowincome area.

Having no formal education was positively associated with $H$. pylori infection. This finding is in agreement with other studies [37-39,41,42]. Education may mediate the observed association by influencing personal and household hygiene practices. Using water from rivers, lakes and streams was associated with 5-fold higher odds of infection compared to using private taps after adjusting for several background variables including location and rural/ urban residence. Studies in Peru [43], Kazakhstan [35] and Brazil $[37,44]$ found an association between $H$. pylori infection and surface water sources, such as rivers, for household use. Fujimura et al. [45] demonstrated that river water in the natural environment could be a risk factor for $H$. pylori transmission. $H$. pylori has previously been detected in drinking water [46,47]. The presence of $H$. pylori in water supplies might be the result of contamination from human sewage [48-51]. We postulate that the use of contaminated surface water sources with inadequate treatment at the household level is involved in the transmission of $H$. pylori infection in Uganda. Interestingly, Apac which had the highest proportion of women using water from rivers, lakes and streams had the lowest prevalence of infection, providing further support for the hypothesis of limited exposure due to "isolation" in that although these are surface water sources, they are not yet contaminated due to the relative isolation of the location.

A limitation of our study is that we used the stool antigen test, which has not been validated for the Ugandan population, to detect $H$. pylori infection. However, the stool antigen test, and specifically the Premier Platinum HpSA test has been evaluated in diverse populations [19,52-56] and has been used widely in Africa [9,55,57-60]. Furthermore, the associations between $H$. pylori infection and the use of surface water sources, low educational attainment and overcrowding, have been reported in other studies thus validating our findings. Other potential limitations include not specifically excluding women who had used proton-pump inhibitors in the two weeks preceding data collection or women with hyperemesis gravidarum.

\section{Conclusions}

In conclusion, this study found that prevalence of $H$. pylori infection in Uganda is not homogeneous but varies by geographic location and by ethnic group. This calls for population-based studies in the region to further describe the epidemiology of $H$. pylori and provides an opportunity to study the transmission dynamics of $H$. pylori infection. The use of rivers, lakes and streams in households is a risk factor for $H$. pylori infection, suggesting waterborne transmission of the infection thus highlighting the need for concerted efforts in environmental health in communities and at the household level. 


\section{Abbreviations}

ANC: Antenatal care; Cl: Confidence Interval; HC: Health Centre; HpSA: H. pylori stool antigen test; OR: Odds ratio.

\section{Competing interests}

The authors declare that they have no competing interests.

\section{Authors' contributions}

RKB and LD conceptualized and designed the study; RKB collected and analysed the data; RKB, LD and JKE interpreted the data; RKB drafted the manuscript; LD and JKE substantially revised the manuscript. All authors reviewed and gave final approval of the version to be published.

\section{Acknowledgements}

The mothers who participated in this study and the health workers at the facilities where data was collected are gratefully acknowledged. This study was supported by a PhD award to RKB from Innovations @Makerere Committee. The funders had no role in the study.

\section{Author details}

${ }^{1}$ Department of Biochemistry and Sports Science, College of Natural Sciences, Makerere University, P. O. Box 7062, Kampala, Uganda. ${ }^{2}$ Kuwait Institute for Scientific Research, Food and Nutrition Program, Environment and Life Sciences Research Center, Kuwait, Saudi Arabia.

Received: 8 April 2014 Accepted: 28 August 2014

Published: 4 September 2014

\section{References}

1. Eslick GD, Lim LL, Byles JE, Xia HH, Talley NJ: Association of Helicobacter pylori infection with gastric carcinoma: a meta-analysis. Am J Gastroenterol 1999, 94(9):2373-2379.

2. Ford AC, Axon AT: Epidemiology of Helicobacter pylori infection and public health implications. Helicobacter 2010, 15(Suppl 1):1-6.

3. Santos IS, Boccio J, Santos AS, Valle NC, Halal CS, Bachilli MC, Lopes RD: Prevalence of Helicobacter pylori infection and associated factors among adults in Southern Brazil: a population-based cross-sectional study. BMC Public Health 2005, 5:118.

4. Goh KL, Cheah PL, Md N, Quek KF, Parasakthi N: Ethnicity and H. pylori as risk factors for gastric cancer in Malaysia: A prospective case control study. Am J Gastroenterol 2007, 102(1):40-45

5. Sasidharan S, Uyub AM, Azlan AA: Further evidence of ethnic and gender differences for Helicobacter pylori infection among endoscoped patients. Trans R Soc Trop Med Hyg 2008, 102(12):1226-1232.

6. Bruce $M G$, Maaroos HI: Epidemiology of Helicobacter pylori infection. Helicobacter 2008, 13(Suppl 1):1-6.

7. Ochama P: Testing for Helicobacter pylori status in patients undergoing diagnostic endoscopy in Mulago and Nsambya Hospitals, Dissertation. Kampala: Makerere University; 2001.

8. Newton R, Ziegler JL, Casabonne D, Carpenter L, Gold BD, Owens M, Beral V, Mbidde E, Parkin DM, Wabinga $H$, Mbulaiteye S, Jaffe H: Helicobacter pylori and cancer among adults in Uganda. Infect Agent Cancer 2006, 1:5

9. Hestvik E, Tylleskar T, Kaddu-Mulindwa DH, Ndeezi G, Grahnquist L, Olafsdottir E, Tumwine JK: Helicobacter pylori in apparently healthy children aged 0-12 years in urban Kampala. Uganda: a community-based cross sectional survey. BMC Gastroenterol 2010, 10:62.

10. Gupta V, Perez-Perez GI, Dorsey G, Rosenthal PJ, Blaser MJ: The seroprevalence of Helicobacter pylori and its relationship to malaria in Ugandan children. Trans R Soc Trop Med Hyg 2012, 106(1):35-42.

11. Yuan W, Li Y, Yang K, Ma B, Guan Q, Wang D, Yang L: Iron deficiency anemia in Helicobacter pylori infection: meta-analysis of randomized controlled trials. Scand J Gastroenterol 2010, 45(6):665-676.

12. Qu XH, Huang XL, Xiong P, Zhu CY, Huang YL, Lu LG, Sun $X$, Rong L, Zhong L, Sun DY, Lin H, Cai MC, Chen ZW, Hu B, Wu LM, Jiang YB, Yan WL: Does Helicobacter pylori infection play a role in iron deficiency anemia? A meta-analysis. World J Gastroenterol 2010, 16(7):886-896.

13. Weyermann M, Rothenbacher D, Gayer L, Bode G, Adler G, Grab D, Flock F, Brenner $\mathrm{H}$ : Role of Helicobacter pylori infection in iron deficiency during pregnancy. Am J Obstet Gynecol 2005, 192(2):548-553.
14. Farag TH, Stoltzfus RJ, Khalfan SS, Tielsch JM: Helicobacter pylori infection is associated with severe anemia of pregnancy on Pemba Island, Zanzibar. Am J Trop Med Hyg 2007, 76(3):541-548.

15. Mulayim B, Celik NY, Yanik FF: Helicobacter pylori infection detected by 14C-urea breath test is associated with iron deficiency anemia in pregnant women. J Obstet Gynaecol Res 2008, 34(6):980-985.

16. Malik R, Guleria K, Kaur I, Sikka M, Radhakrishnan G: Effect of Helicobacter pylori eradication therapy in iron deficiency anaemia of pregnancy - a pilot study. Indian J Med Res 2011, 134:224-231.

17. Santos IS, Boccio J, Davidsson L, Hernandez-Triana M, Huanca-Sardinas E, Janjetic M, Moya-Camarena SY, Paez-Valery MC, Ruiz-Alvarez V, Valencia ME, Valle NC, Vargas-Pinto G, Solano L, Thomas J: Helicobacter pylori is not associated with anaemia in Latin America: results from Argentina, Brazil, Bolivia, Cuba, Mexico and Venezuela. Public Health Nutr 2009, 12(10):1862-1870.

18. Gisbert JP, de la Morena F, Abraira V: Accuracy of monoclonal stool antigen test for the diagnosis of $\mathrm{H}$. pylori infection: a systematic review and meta-analysis. Am J Gastroenterol 2006, 101(8):1921-1930.

19. Leal YA, Cedillo-Rivera R, Simon JA, Velazquez JR, Flores LL, Torres J: Utility of stool sample-based tests for the diagnosis of Helicobacter pylori infection in children. J Pediatr Gastroenterol Nutr 2011, 52(6):718-728.

20. Malfertheiner P, Megraud F, O'Morain C, Bazzoli F, El-Omar E, Graham D, Hunt R, Rokkas T, Vakil N, Kuipers EJ: Current concepts in the management of Helicobacter pylori infection: the Maastricht III Consensus Report. Gut 2007, 56(6):772-781.

21. Uganda Bureau of Statistics.: 2002 Uganda Population and Housing Census Analytical Report. Kampala: Uganda Bureau of Statistics; 2006:23-26.

22. Uganda Bureau of Statistics, Macro International Inc: Calverton, Maryland, USA: UBOS and Macro International Inc; 2007.

23. Uganda Bureau of Statistics, ICF International Inc: Uganda Demographic and Health Survey 2011. Kampala Uganda: UBOS and Calverton, Maryland: ICF International Inc; 2012.

24. Fernando N, Holton J, Zulu I, Vaira D, Mwaba P, Kelly P: Helicobacter pylori infection in an urban African population. J Clin Microbiol 2001 39(4):1323-1327.

25. Mosane TW, Malope BI, Ratshikhopha ME, Hiss DC, Sitas F: Seroprevalence of Helicobacter pylori immunoglobulin $\mathrm{G}$ antibodies in South African mothers and their children. Eur J Gastroenterol Hepatol 2004, 16(1):113-114.

26. Lwanga SK, Lemeshow S: Sample Size Determination in Health Studies: A Practical Manual. Geneva: World Health Organization; 1991.

27. Hosmer DW, Lemeshow S: Applied Logistic Regression. 2nd edition. New York: John Wiley \& Sons; 2000.

28. Goodman KJ, O'Rourke K, Day RS, Wang C, Redlinger T, Campos A, de la Rosa JM: Helicobacter pylori infection in pregnant women from a U.S.-Mexico border population. J Immigr Health 2003, 5(3):99-107.

29. Graham DY, Yamaoka Y, Malaty HM: Thoughts about populations with unexpected low prevalences of Helicobacter pylori infection. Trans $R$ SoC Trop Med Hyg 2007, 101(9):849-851.

30. Kalach N, Desrame J, Bonnet C, Commegeille P, Couturier D, Chaussade S, Hance $P$, Dupont C, Raymond J: Helicobacter pylori seroprevalence in asymptomatic pregnant women in France. Clin Diagn Lab Immunol 2002 9(3):736-737.

31. Farag TH, Stoltzfus RJ, Khalfanc SS, Tielsch JM: Unexpectedly low prevalence of Helicobacter pylori infection among pregnant women on Pemba Island, Zanzibar. Trans R Soc Trop Med Hyg 2007, 101:915-922.

32. Nell S, Eibach D, Montano V, Maady A, Nkwescheu A, Siri J, Elamin WF, Falush D, Linz B, Achtman M, Moodley Y, Suerbaum S: Recent acquisition of Helicobacter pylori by Baka pygmies. PLoS Genet 2013, 9(9):e1003775.

33. Lee $Y Y$, Mahendra Raj S, Graham DY: Helicobacter pylori infection-a boon or a bane: lessons from studies in a low-prevalence population. Helicobacter 2013, 18(5):338-346.

34. Azim Mirghani YA, Ahmed S, Ahmed M, Ismail MO, Fedail SS, Kamel M, Saidia H: Detection of Helicobacter pylori in endoscopic biopsies in Sudan. Trop Doct 1994, 24(4):161-163.

35. Nurgalieva ZZ, Malaty HM, Graham DY, Almuchambetova R, Machmudova A, Kapsultanova D, Osato MS, Hollinger FB, Zhangabylov A: Helicobacter pylori infection in Kazakhstan: effect of water source and household hygiene. Am J Trop Med Hyg 2002, 67(2):201-206.

36. Parente JM, da Silva BB, Palha-Dias MP, Zaterka S, Nishimura NF, Zeitune JM: Helicobacter pylori infection in children of low and high socioeconomic status in northeastern Brazil. Am J Trop Med Hyg 2006, 75(3):509-512. 
37. Zaterka S, Eisig JN, Chinzon D, Rothstein W: Factors related to Helicobacter pylori prevalence in an adult population in Brazil. Helicobacter 2007, 12(1):82-88

38. Yucel O, Sayan A, Yildiz M: The factors associated with asymptomatic carriage of Helicobacter pylori in children and their mothers living in three socio-economic settings. Jpn J Infect Dis 2009, 62(2):120-124.

39. Jafri W, Yakoob J, Abid S, Siddiqui S, Awan S, Nizami SQ: Helicobacter pylori infection in children: population-based age-specific prevalence and risk factors in a developing country. Acta Paediatr 2010, 99(2):279-282.

40. McLaughlin NJ, McLaughlin DI, Lefcort H: The influence of socio-economic factors on Helicobacter pylori infection rates of students in rural Zambia. Cent Afr J Med 2003, 49(3-4):38-41.

41. Moreira ED Jr, Santos RS, Nassri VB, Reis AT, Guerra AL, Alcantara AP, Matos JF, Carvalho WA, Moura CG, Silvani CS, Sant'Ana CS: Risk factors for Helicobacter pylori infection in children: is education a main determinant? Epidemiol Infect 2004, 132(2):327-335.

42. Sykora J, Siala K, Varvarovska J, Pazdiora P, Pomahacova R, Huml M: Epidemiology of Helicobacter pylori infection in asymptomatic children: a prospective population-based study from the Czech Republic. Application of a monoclonal-based antigen-in-stool enzyme immunoassay. Helicobacter 2009, 14(4):286-297.

43. Klein PD, Graham DY, Gaillour A, Opekun AR, Smith EO: Water source as risk factor for Helicobacter pylori infection in Peruvian children. Gastrointestinal Physiology Working Group. Lancet 1991, 337(8756):1503-1506.

44. Rodrigues MN, Queiroz DM, Bezerra Filho JG, Pontes LK, Rodrigues RT, Braga LL: Prevalence of Helicobacter pylori infection in children from an urban community in north-east Brazil and risk factors for infection. Eur $J$ Gastroenterol Hepatol 2004, 16(2):201-205.

45. Fujimura S, Kato S, Kawamura T: Helicobacter pylori in Japanese river water and its prevalence in Japanese children. Lett Appl Microbiol 2004, 38(6):517-521.

46. Hulten K, Han SW, Enroth H, Klein PD, Opekun AR, Gilman RH, Evans DG, Engstrand L, Graham DY, El-Zaatari FA: Helicobacter pylori in the drinking water in Peru. Gastroenterology 1996, 110(4):1031-1035.

47. Samra ZQ, Javaid U, Ghafoor S, Batool A, Dar N, Athar MA: PCR assay targeting virulence genes of Helicobacter pylori isolated from drinking water and clinical samples in Lahore metropolitan, Pakistan. J Water Health 2011, 9(1):208-216.

48. Queralt N, Bartolome R, Araujo R: Detection of Helicobacter pylori DNA in human faeces and water with different levels of faecal pollution in the north-east of Spain. J Appl Microbiol 2005, 98(4):889-895.

49. Lu Y, Redlinger TE, Avitia R, Galindo A, Goodman K: Isolation and genotyping of Helicobacter pylori from untreated municipal wastewater. Appl Environ Microbiol 2002, 68(3):1436-1439.

50. Nayak AK, Rose JB: Detection of Helicobacter pylori in sewage and water using a new quantitative PCR method with SYBR green. J App/ Microbiol 2007, 103(5):1931-1941.

51. Mazari-Hiriart M, Lopez-Vidal Y, Ponce-de-Leon S, Calva JJ, Rojo-Callejas F, Castillo-Rojas G: Longitudinal study of microbial diversity and seasonality in the Mexico City metropolitan area water supply system. Appl Environ Microbiol 2005, 71(9):5129-5137.

52. Korkmaz H, Kesli R, Karabagli P, Terzi Y: Comparison of the diagnostic accuracy of five different stool antigen tests for the diagnosis of Helicobacter pylori infection. Helicobacter 2013, 18(5):384-391.

53. Shimoyama T: Stool antigen tests for the management of Helicobacter pylori infection. World J Gastroenterol 2013, 19(45):8188-8191.

54. Kesli R, Gokturk HS, Erbayrak M, Karabagli P, Terzi Y: Comparison of the diagnostic values of the 3 different stool antigen tests for the noninvasive diagnosis of Helicobacter pylori infection. $J$ Investig Med 2010, 58(8):982-986.

55. Jones RT, Darboe MK, Doherty CP, MacKay WG, Weaver LT, Campbell DI, Thomas JE: Evaluation of 13C-urea breath test and fecal antigen immunoassay to detect Helicobacter pylori infection in Gambian infants. J Pediatr Gastroenterol Nutr 2007, 44(5):650-652.

56. de Carvalho Costa Cardinali L, Rocha GA, Rocha AM, de Moura SB, de Figueiredo Soares T, Esteves AM, Nogueira AM, Cabral MM, de Carvalho AS, Bitencourt P, Ferreira A, Queiroz DM: Evaluation of [13C]urea breath test and Helicobacter pylori stool antigen test for diagnosis of $\mathrm{H}$. pylori infection in children from a developing country. J Clin Microbio/ 2003, 41(7):3334-3335.

57. Smith SI, Oyedeji KS, Goodluck HA, Fowora MA, Anomneze E, Lesi OA: The use of Helicobacter pylori stool antigen test for the diagnosis of Helicobacter pylori in Lagos, Nigeria. West Indian Med J 2011, 60(1):33-35

58. Hestvik E, Tylleskar T, Ndeezi G, Grahnquist L, Olafsdottir E, Tumwine JK, Kaddu-Mulindwa DH: Prevalence of Helicobacter pylori in HIV-infected. HAART-naive Ugandan children: a hospital-based survey. J Int AIDS SOC 2011, 14:34.

59. Ndip RN, Malange AE, Akoachere JF, MacKay WG, Titanji VP, Weaver LT: Helicobacter pylori antigens in the faeces of asymptomatic children in the Buea and Limbe health districts of Cameroon: a pilot study. Trop Med Int Health 2004, 9(9):1036-1040

60. Laving A, Kamenwa R, Sayed S, Kimang'a AN, Revathi G: Effectiveness of sequential v. standard triple therapy for treatment of Helicobacter pylori infection in children in Nairobi, Kenya. S Afr Med J 2013, 103(12):921-924.

doi:10.1186/1471-2458-14-915

Cite this article as: Baingana et al:: Helicobacter pylori infection in pregnant women in four districts of Uganda: role of geographic location, education and water sources. BMC Public Health 2014 14:915.

\section{Submit your next manuscript to BioMed Central and take full advantage of:}

- Convenient online submission

- Thorough peer review

- No space constraints or color figure charges

- Immediate publication on acceptance

- Inclusion in PubMed, CAS, Scopus and Google Scholar

- Research which is freely available for redistribution 